\title{
GAMBARAN TINGKAT KECEMASAN PADA IBU YANG ANAKNYA MENDERITA LEUKEMIA LIMFOBLASTIK AKUT DI RSUP PROF. DR. R. D. KANDOU MANADO
}

\author{
${ }^{1}$ Maria V. I. Rani \\ ${ }^{2}$ Anita E. Dundu \\ ${ }^{2}$ Theresia M. D. Kaunang
}

\author{
${ }^{1}$ Kandidat Skripsi Fakultas Kedokteran Universitas Sam Ratulangi Manado \\ ${ }^{2}$ Bagian Psikiatri Fakultas Kedokteran Universitas Sam Ratulangi Manado \\ Email: mariavirginia194@gmail.com
}

\begin{abstract}
Acute lymphoblastic leukemia (ALL) is a malignat disease that at most was suffered by children. Mothers of children with ALL suffer from prolonged anxiety due to the prolonged treatment of ALL (approximately two years) with a relatively expensive cost. Anxiety is a uncomfortable feeling that appears if someone is dealing with difficult problems. Symptoms of anxiety include heart palpitation, trembling, difficulty in concentrating, excessive sweating, and rapid breathing. This was a descriptive quantitative study with a cross sectional approach. In this study, we used HARS instrument and data were processed by using SPSS 20. The results showed that 30\% respondents had mild anxiety, $26.7 \%$ had medium anxiety, $26.7 \%$ had severe anxiety, and $16.7 \%$ did not have anxiety. Conclusion: In this study, most of the respondents had mild anxiety, followed by mild and severe anxiety. However, some respondents did not suffer from anxiety.
\end{abstract}

Keywords: anxiety, mothers of children with acute lymphoblastic leukemia, HARS

\begin{abstract}
Abstrak: Leukemia limfoblastik akut (LLA) merupakan penyakit keganasan yang paling banyak diderita oleh anak. Penyakit leukemia limfoblastik akut yang diderita oleh anak memberikan dampak kecemasan yang berkepanjangan pada Ibu. Hal ini disebabkan oleh protokol pengobatan yang lama yaitu kurang lebih 2 tahun, dengan biaya yang tergolong mahal. Kecemasan adalah perasaan tidak nyaman yang muncul jika seseorang berhadapan dengan masalah yang berat. Gejala kecemasan diantaranya jantung berdebar, gemetar, sulit berkonsentrasi, keringat berlebihan, dan pernapasan cepat. Penelitian ini bersifat deskriptif kuantitatif dengan pendekatan potong lintang. Penelitian ini menggunakan instrumen HARS dan data yang diperoleh diolah menggunakan SPSS 20. Hasil penelitian menunjukkan sebanyak 30\% responden mengalami kecemasan ringan, 26,7\% dengan kecemasan sedang, 26,7\% dengan kecemasan berat, sedangkan 16,7\% responden tidak mengalami kecemasan. Simpulan: Pada penelitian ini didapatkan responden terbanyak mengalami kecemasan ringan, diikuti oleh kecemasan sedang dan berat. Sebagian kecil responden tidak mengalami kecemasan.
\end{abstract}

Kata kunci: kecemasan, ibu yang anaknya menderita LLA, HARS

Leukemia adalah penyakit keganasan pada jaringan hematopoietik yang ditandai dengan penggantian elemen sumsum tulang normal oleh sel darah abnormal atau sel leukemik. ${ }^{1}$ Insiden leukemia mencapai kurang lebih 33\% dari keganasan pediatrik, paling banyak ialah kasus leukemia limfoblastik akut. ${ }^{2}$ The American Cancer 
Society memperkirakan di Amerika pada tahun 2014 terdapat 6020 kasus baru leukemia limfoblastik akut pada orang dewasa dan anak-anak. ${ }^{3}$

Berdasarkan hasil Riset Kesehatan Dasar (Riskesdas) tahun 2013 jumlah penderita kanker di Indonesia selain kanker serviks dan prostat adalah 1.027 .763 jiwa. ${ }^{4}$ Berdasarkan data rekam medik RSUP Prof. Dr. R. D. Kandou Manado sepanjang tahun 2008-2012 jumlah anak yang menderita leukemia limfoblastik akut sekitar 60 anak yang rawat inap di bagian Estella Prof. Dr. R. D. Kandou. ${ }^{5}$

Diagnosis kanker pada anak merupakan sebuah pukulan berat bagi orangtua. Pada umumnya orangtua setelah mengetahui anaknya mengidap kanker mereka akan merasa shock, tidak percaya, takut, merasa bersalah, sedih, cemas dan marah. ${ }^{6}$ Selain itu, mendampingi anak menjalani pengobatan kanker akan memberikan dampak stress yang berat dan berkepanjangan pada orangtua, terutama ibu. ${ }^{7}$ Hal ini bisa disebabkan karena ibu lebih banyak menghabiskan waktu untuk merawat anak.

Masalah-masalah akibat penyakit leukemia limfoblastik akut yang dapat memicu stres pada ibu ialah pengobatan yang cukup lama (kurang lebih 2 tahun), biaya pengobatan yang tergolong mahal, dan bisa menyebabkan kematian pada anak. Seseorang yang mengalami stres berkepanjangan rentan mengalami gangguan kejiwaan; salah satunya ialah kecemasan. Kecemasan ditandai dengan perasaan tidak nyaman, ketakutan, disertai gejala otonom seperti palpitasi sesak napas dan ketegangan otot. ${ }^{8}$

Penelitian yang dilakukan oleh Pratap Sharan dan rekannya tahun 1999 di India pada orangtua yang anaknya mengidap leukemia limfoblastik akut ditemukan kurang lebih $20-30 \%$ orangtua mengalami kecemasan dan memerlukan perawatan psikiatri. ${ }^{9}$ Penelitian yang dilakukan oleh Grootenhuis tahun 1997ditemukan bahwa ibu yang anaknya mengidap kanker mengalami tekananyang lebih berat dibandingkan ayah. ${ }^{10}$ Penelitian lain yang dilakukan oleh Khalifa dan rekannya tahun 2014 ditemukan bahwa orangtua yang anaknya mengidap leukemia limfoblastik akut mengalami kecemasan terutama ibu. ${ }^{11}$ Pada penelitian lain yang dilakukan oleh Simon tahun 2002 ditemukan bahwa wanita lebih rentan mengalami distress, kecemasan dan depresi apabila menghadapi suatu stresor. ${ }^{12}$

Penelitian ini bertujuan untuk mengetahui gambaran tingkat kecemasan ibu yang anaknya dirawat di RSUP Prof. dr. R. D. Kandou Manado akibat menderita penyakit leukemia limfoblastik akut.

\section{METODE PENELITIAN}

Penelitian yang dilakukan bersifat deskriptif kuantitatif dengan pendekatan potong lintang. Populasi penelitian ialah ibu yang anaknya menderita leukemia limfoblastik akut dan menjalani pengobatan di RSUP Prof. Dr. R. D. Kandou Manado pada periode bulan Oktober - Desember 2014. Pemilihan sampel menggunakan cara consecutive sampling, yaitu semua subyek yang ditemukan dan memenuhi kriteria inklusi dimasukkan dalam penelitian hingga jumlah subyek yang diperlukan terpenuhi.

Jumlah sampel yang memenuhi kriteria inklusi dan ekslusi berjumlah 30 responden. Jumlah ini didapatkan dari total responden yang mengantarkan anaknya untuk menjalani pengobatan dan respsonden yang mendampingi anak yang dirawat inap di Rumah Sakit RSUP Prof. Dr. R. D. Kandou selama periode bulan Oktober - Desember 2014. Pengumpulan data menggunakan kuesioner sosiodemografik dan HARS.

\section{HASIL PENELITIAN}

Berdasarkan hasil penelitian yang dilakukan terhadap 30 responden didapatkan, responden paling banyak terlibat dalam penelitian ialah responden yang termasuk kategori usia 26-35 tahun 
yaitu 14 orang (46,7\%). Responden paling banyak berpendidikan akhir tamat SMA/SLTA yaitu 16 orang (53,3\%). Mayoritas responden yang telibat dalam penelitian beragama Kristen sebanyak 21 orang (70\%). Responden yang paling banyak terlibat dalam penelitian ialah responden yang tidak bekerja sebanyak 21 orang (70\%). Sebagian besar responden memiliki anak lebih dari 1 yaitu berjumlah 24 orang (80\%). Responden yang terlibat dalam penelitian memiliki anak perempuan sebanyak 16 orang (53,3\%) sedangkan yang memiliki anak lelaki sebanyak 14 orang (46,7\%) (Tabel 1).

Tabel 1. Distribusi frekuensi karakteristik demografi Ibu yang anaknya menderita leukemia limfoblastik akut

\begin{tabular}{lcl}
\hline $\begin{array}{c}\text { Karakteristik } \\
\text { Responden }\end{array}$ & $\begin{array}{c}\text { Frekuensi } \\
\text { (n) }\end{array}$ & \% \\
\hline Umur & & \\
$17-25$ tahun & 2 & 6,7 \\
$26-35$ tahun & 14 & 46,7 \\
36-45 tahun & 12 & 40,0 \\
46-55 tahun & 2 & 6,7 \\
Pendidikan & & \\
Terakhir & 5 & 16,7 \\
SD & 6 & 20,0 \\
SMP/SLTP & 16 & 53,3 \\
SMA/SLTA & 3 & 10,0 \\
PT & & \\
Agama & 21 & 70,0 \\
Kristen & 8 & 26,7 \\
Islam & 1 & 3,3 \\
Katolik & 0 & 0,0 \\
Budha & 0 & 0,0 \\
Hindu & 0 & 0,0 \\
Konghuchu & & \\
Pekerjaan & & \\
Bekerja & 9 & 30,0 \\
Tidak Bekerja & 21 & 70,0 \\
Jumlah Anak & & \\
Anak Tunggal & 6 & 20,0 \\
> 1 anak & 24 & 80,0 \\
Jenis Kelamin & & \\
Anak & & \\
Lelaki & 14 & 46,7 \\
Perempuan & 16 & 53,3 \\
\hline
\end{tabular}

Berdasarkan hasil penelitian didapatkan bahwa ibu yang memiliki anak yang mengidap leukemia limfoblastik akut paling banyak mengalami kecemasan ringan sebanyak 9 orang (30\%). Jumlah Ibu yang mengalami kecemasan sedang dan kecemasan berat sebanyak 8 orang (26,7\%). Selanjutnya jumlah Ibu yang tidak mengalami kecemasan sebanyak 5 orang (16,7 \%) dan tidak ada dari responden yang mengalami kecemasan sangat berat (Tabel 2).

Tabel 2. Distribusi frekuensi tingkat kecemasan responden

\begin{tabular}{lcc}
\hline $\begin{array}{c}\text { Tingkat Kecemasan } \\
\text { Responden }\end{array}$ & Frekuensi & $\mathbf{\%}$ \\
\hline Tidak & & \\
Ada Kecemasan & 5 & 16,7 \\
Kecemasan Ringan & 9 & 30,0 \\
Kecemasan Sedang & 8 & 26,7 \\
Kecemasan Berat & 8 & 26,7 \\
Kecemasan Sangat & 0 & 0,0 \\
Berat & & \\
\hline Total & $\mathbf{3 0}$ & $\mathbf{1 0 0}$ \\
\hline
\end{tabular}

\section{BAHASAN}

Berdasarkan hasil penelitian ditemukan bahwa responden terbanyak adalah responden yang berada dalam kategori usia 26-35 tahun berjumlah 14 orang (46,7 \%) yang kemungkinan mengalami kecemasan. Berdasarkan data epidemiologi bahwa sebanyak 80\% kasus gangguan kecemasan bermanifestasi sebelum usia 35 tahun. ${ }^{13}$ Paling banyak responden yang berpartisipasi dalam penelitian ini pendidikan akhirnyaSMA berjumlah 16 orang (53,3 $\%$ ); hal ini menunjukan bahwa responden memiliki jenjang pendidikan yang cukup baik.

Paling banyak responden tidak bekerja atau berprofesi sebagai ibu rumah tangga berjumlah 21 orang (70\%). penelitian yang dilakukan oleh Khalifa dan rekannya pada orangtua yang anaknya mengidap leukemia limfoblastik akut ditemukan bahwa responden yang memiliki profesi yang 
Rani, Dundu, Kaunang: Gambaran tingkat kecemasan...

rendah lebih rentan mengalami kecemasanberat. ${ }^{11}$ Paling banyak responden menganut agama Kristen yaitu 21 orang (70\%). Agama Kristen merupakan agama yang paling banyak dianut oleh masyarakat Sulawesi Utara. Responden yang memiliki anak tunggal jumlahnya 6 orang (20\%) sisanya 24 orang (80\%) responden memilki lebih dari satu anak. Paling banyak dari responden memiliki anak perempuan berjumlah 16 orang (53,3\%) sedangkan anak laki-laki berjumlah 14 orang $(46,7 \%)$.

Kanker menciptakan krisis dalam kehidupan setiap anggota keluarga. Diagnosis kanker pada anak merupakan pukulan berat bagi orangtua terutama Ibu yang mengandung dan membesarkan anak tersebut.Menurut Ghodsbin dan rekannya bahwa penyakit kronis seperti kanker memberikan dampak bagi orang tua, mereka akan mengalami ketakutan, kecemasan, dan gangguan mental lainnya. ${ }^{14}$ Penelitian yang dilakukan oleh Hagedoorn dan rekan menemukan bahwa orangtua yang memiliki anak dengan kanker memiliki resiko lebih besar untuk mengalami gangguan kecemasan dibandingkan dengan orangtua yang memiliki anak sehat. ${ }^{15}$ Penelitian yang dilakukan oleh Delavari dan rekannya tahun 2014 ditemukan bahwa ibu yang anaknya menderita kanker memiliki tingkat kecemasan yang lebih tinggi dibandingkan ayah yang anaknya menderita kanker. ${ }^{16}$

Berdasarkan hasil penelitian sebanyak $83,4 \%$ ibu yang anaknya menderita leukemia limfoblastik akut mengalami kecemasan ringan hingga berat. Hasil penelitian ini berbeda dengan hasil penelitian yang dilaporkan oleh Pratap Sharan et al. yaitu kurang lebih 20-30\% orangtua yang anaknya mengidap leukemia limfoblastik akut mengalami kecemasan; sisanya mengalami gangguan psikiatri lainnya. ${ }^{9}$ Perbedaan jumlah responden yang mengalami kecemasan bisa disebabkan oleh perbedaan lingkungan, sosial budaya, dan kemampuan mengatasi masalah dari masing-masing individu. ${ }^{17}$

\section{SIMPULAN}

Berdasarkan hasil penelitian yang telah dilakukan dapat disimpulkan bahwa responden yang paling banyak ialah yang dengan tingkat kecemasan ringan sedangkan yang paling sedikit ialah yang tidak mengalami kecemasan.

\section{DAFTAR PUSTAKA}

1. Rofinda ZD. Kelainan Hemostasis pada leukemia. Jurnal kesehatan Andalas. 2012;1:68-74.

2. Crist WM, Pui CH. Leukemia. Dalam: Nelson WE, Behrman RE, Kliegman R, Arvin AM, Wahab AS. Nelson: Ilmu kesehatan anak. Edisi ke-15. Jakarta: EGC; 2012. p. 1772.

3. America cancer society. Leukemia: acute lymphocytic overview. $2014 \mathrm{Feb}$ 7[cited 2014 Oct 04]. Available from: http://www.cancer.org/acs/groups/cid /documents/webcontent/003054pdf.pdf

4. Riset Kesehatan Dasar (Riskesdas) 2013. Jakarta: Badan Litbangkes, Depkes RI, 2013.

5. Pinontoan E, Mantik M, Rampengan N. Pengaruh kemoterapi terhadap profil hematologi pada penderita leukemia limfoblastik akut. Jurnal UNSRAT. 2012:1-6.

6. American Cancer Society. Children diagnosed with cancer: dealing with diagnosis. 2014 Oct 9 [cited 2015 Jan 10]. Available from:

http://www.cancer.org/acs/groups/cid /documents/webcontent/002592pdf.pdf

7. Gudmundsdottir E, Hornquist L, Boman KK. Psychological outcomes in Swedish and Icelandic parents following a child's cancer-in the light of site-related differences. Support care cancer. 2012; 21:1637-45.

8. Jiloha RC, Bhatia MS. Psychiatry for general practitioners. New delhi: New age international publisher; 2010. p.76. 
9. Sharan P, Mehta M, Caudhry VP. Psyciatric disorders among parents of children suffering from acute lymphoblastic leukemia. Pediatric Hematology and Oncology. 1999;16:43-7.

10.Grootenhuis MA, Last BF. Predictors of parentalemotional adjustment to childhood cancer. Psycho-Oncology. 1997;6:115-128.

11. Khalifa AS, Bishry Z, Tantawy AAG, Ghanem MH, Effat SM, et al. Psychiatric morbidity in Egyptian children with acute lymphoblastic leukemia and their care providers. 2014;7:76-84.

12. Simon R. Revisiting the relationships among gender, marital status and mental health. Sociology. 2002;107:1065-1096.

13. Michael T,Zetsche $U$, Margraf $J$. Epidemiology of anxiety disorder. 2007 [cited 2015 Jan 5]. Available from:http://www.sciencedirect.com/s cience/article/pii/S147617930670065 9

14. Ghodsbin F, Asadi N, Fard SJ, Kamali M. Effect of education on quality of life of family caregivers of chilfren with leukemia referred to the oncology clinic at kerman; AfzaliPoor Hospital. 2012;32.

15. Hagedoorn MT, Kreicbergs U, Appel C. Coping with cancer: the perspective of patients relatives.Acta Oncologica. 2011;50:205-11.

16. Delavari $H$, Nasirian $M$, Bafrooei $K B$. Logo therapy effect on anxiety and depression in mothers of children with cancer. Pediatrichematology and oncology. 2014;4:42-7.

17. Twenge JM. The age of anxiety? birth cohort change in anxiety and neuroticism, 1952-1993. Journal of personality and social psychology. 2000;79:1007-21. 